\title{
VERBAL REPRESENTATION OF EXISTENTIAL ISSUES IN HAROLD PINTER'S PLAY THE CARETAKER
}

\begin{abstract}
Summary. The article is devoted to the analysis of one of early plays by English absurdist playwright of XXXXI c. - Harold Pinter. The object of our investigation is the text of the play The Caretaker by Harold Pinter, and its subject is verbal representation of existential issues in the play. As it is known, the philosophy of Existentialism and main ideas of A. Camus and J.-P. Sartre influenced the formation of drama of absurd as a genre. Hence the goal of the article is to study verbal representation of existential issues in Harold Pinter's play The Caretaker from linguostylistic point of view. The focus is on such existential issues as: menacing intrusion into a human dwelling; aggression and violence as a feature of contemporary society; human inability and unwillingness to communicate with others; human isolation, loneliness and desperation in modern world. In his play, H. Pinter shows an unhappy, reserved person locked up in a small shell and unwilling to leave it. Characters' dialogue and author's remark have been analyzed in our research. It has been revealed that dominant lingual means of expression of existential issues in the work are repetition at morphological, lexical and syntactic levels; irony; climax; aposiopesis; parallel constructions; time fillers and incomplete, elliptical sentences. The characters' dialogue is often illogical, inconsistent, without personages' response cues to previous utterances of their interlocutors and with frequent change of conversation topics due to main characters' unwillingness to develop them. The effect of absence of human communication and their reluctance to socialize is strengthened by constantly used author's remark "pause" and "silence". Nevertheless, personages' utterances are emotional - the information obtained from the author's remark denoting certain emotional state of speakers - worry, anxiety, fear, aggression, pain etc.
\end{abstract}

Key words: drama of absurd, philosophy of existentialism, existential issues, characters' dialogue, author's remark, dominant linguistic means.

Formulation of the problem. The term "The Theatre of the Absurd" refers to dramatic works of certain European and American dramatists of the 1950s and early '60s [1]. When first performed, these plays shocked their audiences as they were startlingly different from anything that had been previously staged. In fact, many of them were labeled as "anti-plays". In an attempt to clarify and define this radical movement, Martin Esslin coined the term "The Theatre of the Absurd" in his book entitled "The Theatre of the Absurd". He defined it as such, because all of the plays emphasized the absurdity of the human condition [2]. According to Martin Esslin, "absurd" originally means "out of harmony" in a musical context. Hence, its dictionary definition is "out of harmony with reason or propriety; incongruous, unreasonable, illogical". In common usage in the English-speaking world, "absurd" may simply mean "ridiculous". But this is not the sense in which Camus uses the word, and in which it is used when we speak of the Theatre of the Absurd. Esslin uses Ionesco's understanding of the term: "absurd is that which is devoid of purpose... Cut off from his religious, metaphysical and transcendental roots, a man is lost; all his actions become senseless, absurd, useless" [3, XIX].

Each play of the Theatre of the Absurd shows man's existence as illogical and meaningless. According to Susan C.W. Abbotson, this idea was a reaction to the "collapse of moral, religious, political, and social structures" after two World Wars of the Twentieth Century [4, p. 1]. Among the English representatives of The Theatre of the Absurd are Samuel Beckett, Harold Pinter and Tom Stoppard.

Absurdist Theatre was heavily influenced by Existential philosophy. It aligned best with the philosophy in Albert Camus' essay The Myth of Sisyphus. In this essay, Camus attempts to present a reasonable answer as to why a man should not commit suicide in face of a meaningless, absurd existence. To do so, he uses the Greek mythological figure, Sisyphus, who was condemned to push a boulder up a mountain, only to have it roll back down. He repeats this futile cycle for all of eternity [2]. On the final pages of the essay, Camus states that "One must imagine Sisyphus happy" $[5$, p. 78$]$. He means that the struggle of life alone should bring one's happiness. Essentially, we can find meaning in living even without knowing why we exist. The absurd dramatists, however, did not resolve the problem of man's meaningless existence quite as positively as Camus. In fact, they offered no solution to the problem, suggesting that the question is ultimately unanswerable [2].

Analysis of recent research and publications. Pinter's play The Caretaker has been an object of numerous recent investigationsÖzkan Kırmızı and Zeynep Kurt Yıldız have applied a Freudian psychoanalytic approach to the play focusing on neurotic disorder and alienation [6]; Basaad Albadri Mhayyal has explored silence as a means of communication in the play [7]; Mangesh R. Adgokar has studied menace and violence of unspecific forces in the play [8]; Prashant Mandre has investigated the theme of allegiance and meaninglessness of life in the play [9]; Arwind Nawale's article deals with pragmatics and focuses on a study of deixis in Pinter's play [10]; Anila Jamil's article gives a psychoanalytic reading of the play The Caretaker concentrating on society's role in creating neurotics [11]; Mari Anne Kyllesdal in her thesis analyses repetition patterns in Pinter's plays The Hothouse and The Caretaker [12]. Each research deals with a certain, specific aspect. In our investigation we have decided to combine literary and linguistic approaches and explore not only the existential issues raised in the play but also their verbal representation.

The aim of the article is to study the text of the play The Caretaker from linguostylistic point of view focusing on dominant 
stylistic devices and expressive means through which existential issues are verbalized in H. Pinter's play.

The presentation of the main research material. The Caretaker is one of Pinter's early plays written in 1959. Just like his play The Room and S. Beckett's famous play Waiting for Godot, it is devoid of plot and action. The focus is on characters' dialogue and author's remark. The play has only three characters and its three acts narrate a night in winter and scenes a few seconds later and a fortnight later. This three-act play describes the appearance of an old tramp, Davies, in a flat of two brothers - Aston and Mick and the way it changes lives of both brothers.

One of the central and recurring motifs is the motif of intrusion. At the beginning of the play, in act one, a stranger appears in Aston's dwelling. As a reader finds out, Aston saves Davies from a bar fight (Davies: If you hadn't come out and stopped that Scotch git I'd be inside the hospital now. I'd have cracked my head on that pavement if he'd have landed... [13, p. 19]) and invites a homeless man to his flat (Davies: Anyway, I'm obliged to you, letting me ... letting me have a bit of a rest, like ... for a few minutes... [13, p. 19-20]). At first, Davies seems to be a simple, illiterate, man. All his cues contain graphon (That was after the guvnor give me the bullet [13, p. 19]; Oh, they're ... they're all right, en't they? [13, p. 26]; This ain't your room... I ain't never seen you before [13, p. 41]); plenty of colloquial words (git; caff; bastard; piss off; bloke; bloody; nigs; dead out; bugger; damn; chap; arse; punch up; fibber; spiky; off your nut; muck about; pal; lousy; nuthouse; nutty; half way gone; what the hell) and are grammatically incorrect (When he come at me tonight...[13, p. 17]; The pan for vegetables, it was [13, p. 18]; ... we was brought up with the right ideas [13, p. 19]; You sleep here, do you? [13, p. 20]; ... there was someone was living in the house [13, p. 21]; Meal they give me! [13, p. 23]; Good shoe this [13, p. 24]; I been going around an assumed name! [13, p. 29]; Them noises [13, p. 32]; I don't make no noises [13, p. 37]). Having pity on a simple, helpless, shabby, old man, Aston not only offers him a bed in his flat but also gives him some coins and tobacco to fill his pipe, and brings him a pair of shoes. Gradually a reader changes his mind about Davies, who, despite all the kindness of Aston, is ungrateful, thus, revealing his true nature. Firstly, he is unwilling to sleep in the offered room because of draughts:

Davies: Gets very draughty.

Aston: Ah.

Davies: I'm very sensitive to it.

Aston: Are you?

Davies: Always have been. Pause. You got any more rooms then, have you? [13, p. 20].

Later, in act two, Davies comes into conflict with Aston because of the opened window near his bed:

Davies: ... Draught's blowing right in on my head, anyway. Pause. Can't you

close that window behind that sack?

Aston: You could.

Davies: Well then, what about it, than? The rain's coming right in on my head.

Aston: Got to have a bit of air.

Aston: Why don't you sleep the other way round? ... Sleep with your feet to the

window...

Davies: No, I couldn't do that. I mean, I got used to sleeping this way [13, p. 61-62].
Also, Davies is dissatisfied with the shoes, which Aston brings specially for him, and boldly shows it:

Davies waggles his feet.

Davies: Don't fit though.

Aston: Oh?

Davies: No. I got a very broad foot.

Aston: Mmnn.

Davies: These are too pointed, you see.

Aston: Ah.

Davies: They'd cripple me in a week. I mean these ones I got on, they're no good but at least they're comfortable... [13, p. 24-25].

In addition to it, trying to make both brothers quarrel, in a conversation with Aston's brother Mick, he says about Aston that "he is nutty and half way gone" [13, p. 82] and "he don't like work" $[13$, p. 58$]$.

Ultimately, at the end of act three, Davies banishes Aston from his own flat exclaiming "You! You better find somewhere else!... I live here..." [13, p. 77].

Thus, Pinter represents Davies as a menacing stranger intruding into home lives and personal relationship of both brothers. Throughout the whole play Davies is called a "foreigner" [13, p. 42], "fibber" [13, p. 43], "robber" [13, p. 44], "barbarian" [13, p. 44], an "old scoundrel" [13, p. 44] and "an impostor" [13, p. 81] by Mick. The playwright uses an irony to show Davies as a menace, as an intruder - throughout the whole play a word "caretaker" and its derivative "caretaking" is used 15 times [13, p. 51-83]. According to the plot, the younger brother Mick offers Davies to stay in the flat and become a caretaker. Even the play is ironically entitled The Caretaker. One more detail characterizing Davies in a negative way is the fact that he is dishonest and untrustworthy using false name:

Davies: You see, what it is, you see, I changed my name! Years ago. I been going around under an assumed name! That's not my real name.

Aston: What name you been going under?

Davies: Jenkins. Bernard Jenkins. That's my name ... [13, p. 29].

An old man is associated with aggression and violence. For example, a few times Davies is described with a knife: "I got a knife here. I'm ready. Come on then, who are you?" [13, p. 54]; "I got a knife, sure I got a knife..." [13, p. 68]; Davies points the knife [13, p. 78]; "I'LL STINK YOU!" He thrusts his arm out, the arm trembling, the knife pointing at Aston's stomach. Aston does not move. Silence. Davies' arm moves no further. They stand [13, p. 78]; Davies draws the knife in to his chest, breathing heavily... [13, p. 78]. It is Mick who notices the violence and aggression of Davies:

Mick: Eh, you're not thinking of doing any violence on me, are you? You're not

violent sort, are you? [13, p. 55];

Mick: Watch your step, sonny! You're knocking at the door when no one's at

home. Don't push it too hard. You come busting into a private house,

laving your hands on anything you can lay your hands on. Don't overstep

the mark, son [13, p. 47];

Mick swiftly forces him to the floor, with Davies struggling, grimacing, whimpering and staring [13, p. 37];

Mick: You're violent, you're erratic, you're just completely unpredictable [13, p. 82]. 
In the last quote climax (violent, erratic, completely unpredictable) even strengthens Davies' ruthlessness.

One can easily spot a repeated noun "harm" [13, p. 58-68] used by personages implicitly, and it becomes obvious that this word is referred to Davies - he is the one who does harm, ruins everything.

Not only Davies is associated with cruelty and aggression. Human cruelty and violence is revealed in Aston's monologue in act two, which is considered the climax of the play. Aston recalls his past when he was taken to mental hospital and given electric shock therapy: ...Then one day they took me to a hospital, right outside London... I didn't want to go... Then one day ... this man ... doctor ... said we're going to do something to your brain... if we don't, you'll be in here for the rest of your life...I tried to escape... they caught me, anyway... they started to come round and do this thing to the brain... they looked like big pincers, with wires on, the wires were attached to a little machine. It was electric... [13, p. 64-65]. Aston's utterance is so emotional that it is full of break-in-the-narrative he is nervous and fearful remembering the tortures he experienced in the past. Except for aposiopesis, Aston's anxiety is also verbally expressed by anaphora (each sentence of his speech begins with repeated personal pronoun "they") and parallel constructions: they got me there...; they asked me questions...; they'd concluded their examination...; they wanted to know...; they caught me...; they started to come round...; ... what they did to the others; they used to hold the man down...; they'd cover the man up ...; they told me to get on the bed...; they had to get me on the bed... [13, p. 64-65]. Aston shares a detailed description of inhumane treatment in hospital: "I knew they had to get me on the bed because if they did it while I was standing up they might break my spine ... I laid one of them out and I had another one round the throat, and then suddenly this chief had these pincers on my skull and I knew he wasn't supposed to do it while I was standing up..." [13, p. 65]. When Aston finishes his monologue with the consequences of his being in this hospital, an auxiliary verb "couldn' $t$ " becomes the key word: "I got out of the place ... but I couldn't walk very well ... I couldn't think at all ... I couldn't ... get ... my thought ... together ... I could ... never quite get it ... together... I couldn't hear what people were saying. I couldn't look to the right or the left ... I couldn't keep ... upright... I should have been dead. I should have died. Anyway, I feel much better now. But I don't talk to people now" [13, p. 66]. Even though this nightmare has ended and a period of time has passed, Aston is still unable to realize himself in this life and be a part of society.

One more existential topic raised in the play is human inability to communicate. Harold Pinter shows that people have become isolated, withdrawn and unwilling to listen to others and, what is more important, hear them and communicate with them. All the utterances of each character are unfinished, incomplete, with elliptical sentences and aposiopesis:

Aston: You Welsh?

Pause.

Davies: Well, I been round, you know ... what I mean ... I been about ...

Aston: Where were you born then?

Davies (darkly): What do you mean?

Aston: Where were you born?

Davies: I was ... uh ... oh, it's a bit hard, like, to set your mind back ... see

what I mean ... going back ... a good way ... lose a bit of track, like ... you know ...
Aston (going to below the fireplace): See this plug. Switch it on here, if you like.

This little fire... [13, p. 34-35].

In the above-mentioned dialogue, Davies does not answer his interlocutor's question postponing his reply and using some senseless phrases, time fillers and aposiopesis. One more obvious linguistic peculiarity of this dialogue is that Aston immediately switches to the other topic of conversation without any logical connection with the previous one. Not only characters' dialogue reflects human inability and unwillingness to communicate but also author's remark explicitly points at it. Pinter's most frequent remarks are "silence" (16 examples) and "pause" (161 examples) constantly used to show that personages remain silent and do not interact.

One more issue raised in Harold Pinter's play is human loneliness. Pinter's characters are lonely and this solitude is expressed through Aston and Davies. Aston lives in his flat all alone, his younger brother Mick is a rare guest in his home. That is why all the time he busies himself with something - screwing and unscrewing the plug, trying to fix the toaster and doing some other unnecessary housework: He crosses down right, to get the electric toaster [13, p. 18]; Aston goes back to his bed with the toaster and starts to unscrew the plug [13, p. 19]; Aston crosses to the plug box to get another plug [13, p. 19]; Aston puts a drawer against the wall [13, p. 27]; Aston picks up a screwdriver and plug from the bed and begins to poke the plug [13, p. 28]; Aston sits, poking his plug [13, p. 30]; Aston goes to his bed, picks up the plug and shakes it [13, p. 31]; Aston stands, goes to the sideboard drawer, right, picks up the statue of Buddha, and puts it on the gas stove [13, p. 49]; Aston picks up the plug and examines it [13, p. 51]; Aston crosses to the chair, puts the plank on it, and continues sandpapering [13, p. 62]; He then goes to his bed, ... takes the screwdriver and plug and pokes the plug [13, p. 84]. All his monotonous and repetitive actions are expressed by homogeneous verbs as well as morphological and lexical repetition. Because of this loneliness he invites an unknown person, a stranger, to his accommodation and even shares his intimate memories about electric shock therapy given to him in mental hospital in the past. Also, Aston is forlorn because after it he fears and mistrusts people, not mentioning the fact that after this treatment he is physically unable to communicate with others: "... my thoughts ... had become very slow ... I couldn't think at all ... I couldn't ... get ... my thought ... together ... I couldn'thear what people were saying..." [13, p. 66]. As for Davies, he is also solitary and miserable. He has no family, no friends, no place to live, no belongings, no money - nothing; he is devoid of everything: "That's very kind of you, mister. Just enough to fill my pipe, that's all. (He takes a pipe from his pocket and fills it.) I had a tin, only ... only a while ago. But it was knocked off. It was knocked off on the Great West Road" [13, p. 17]; "Ileft my wife ... and I haven't seen her since" [13, p. 18]; "I wouldn't mind so much but I left all my belongings in that place, in the back room there. All of them, the lot there was, you see, in this bag" [13, p. 19]; "I got this mate at Shepherd's Bush. In the convenience. Well, he was in the convenience. Run about the best convenience they had. Run about the best one. Always slipped me a bit of soap, any time I went in there. Very good soap... I was never without a piece of soap, whenever I happened to be knocking about the Shepherd's Bush area. He's gone now. Went. He was the one who put me on to this monastery" [13, p. 22]; "Piss off, he said to me ... If you don't piss off, he says, I'll kick you all the way to the gate ...Get out round 
the corner to the kitchen, he says, get out round the corner, and when you've had your meal, piss off out of it" [13, p. 23]; "Aston: How are you off for money? - Davies: Oh well ... now, mister, if you want the truth ... I'm a bit short. You see, I got nothing for all that week's work I did last week" [13, p. 28].

At first sight Pinter's characters resemble puppets that do the same work and the same actions every day, without any changes - roll cigarettes, fix appliances, pick up the statue of Buddha and put it on the gas stove, put a drawer against the wall, shake blankets, move the sack at the window, put a bucket to catch the rain water, put on and take off clothes and shoes, look out of the window, open and close the door, look about the room, open the case etc. However, while reading further on, one cannot but notice that all the characters experience a range of emotions, they are not as indifferent as they may seem. The playwright expresses their emotions in a plentiful author's remark: with great feeling [13, p. 28]; suddenly becomes aware [13, p. 30]; darkly [13, p. 34]; anxiously [13, p. 35]; holds out a warning finger [13, p. 38]; a violent bellow from Mick sends him back [13, p. 42]; groaning [13, p. 42]; quietly ... again amiable, banging on floor [13, p. 42]; stares warily $[13$, p. 43]; abruptly [13, p. 46]; moves, stumbles, falls and cries out $[13$, p. 54]; vehemently [13, p. 55]; ruminatively [13, p. 69]; rising, briskly [13, p. 80]; passionately [13, p. 83]; both are smiling, faintly [13, p. 84]; both remain still [13, p. 87].

Conclusion. Thus, we can see that $H$. Pinter draws our attention to a range of crucial existential problems in his play The Caretaker. Pinter's work shows a modern society where everyone is locked up in their own home because of fear of intrusion and the feelings of solitude and mistrust. According to the playwright, every person metaphorically hides himself or herself in a shell unwilling to communicate and interact with others as the world surrounding them is full of violence, aggression and unpredictability. The author, appealing to a reader, has encoded this message in characters' dialogue and author's remark by means of linguistic stylistic peculiarities of the text.

\section{References:}

1. Encyclopaedia Britannica. URL: https:/www.britannica.com/art/ Theatre-of-the-Absurd.

2. Samer Ziyad Al Sharadgeh. The Theatre of the Absurd. URL: https:// www.researchgate.net/publication/342109178_The_Theater_of_the Absurd.

3. Esslin M. The Theatre of the Absurd. New York : Anchor Books, 1961. $364 \mathrm{p}$.

4. Abbotson S. Thematic guide to modern drama. Westport, Connecticut, London : Greenwood Press, 2003. 293 p.

5. Camus A. The Myth of Sisyphus and other Essays. URL: http://people. brandeis.edu/ teuber/Albert_Camus_The_Myth_of_Sisyphus_ Complete_Text_pdf.

6. Kırmızı Ö. and Kurt Yıldız Z. A Freudian psychoanalytic approach to Harold Pinter's The Caretaker. URL: https://ufuk.edu.tr/uploads/page/ enstituler/sosyal-bilimler/ensdergi/say-17/97-110.pdf.

7. Basaad Albadri Mhayyal Silence as a means of communication in Harold Pinter's The Caretaker. URL: https://www.researchgate.net/ publication/331346776_Silence_as_a_Means_of_Communication in_Harold_Pinter\%27s_The_Caretaker.
8. Mangesh R. Adgokar A study of menace and violence of unspecific forces in The Caretaker. URL: https://www.jetir.org/papers/ JETIR1711156.pdf.

9. Mandre P. The theme of allegiance and meaninglessness of life in Harold Pinter's The Caretaker. URL: http://www.epitomejournals. com/VolumeArticles/FullTextPDF/275_Research_Paper.pdf.

10. Nawale A. A study of deixis in Pinter's The Caretaker. URL: https:// www.researchgate.net/publication/315924490_A_Study_of_Deixis_ in_Pinter\%27s_The_Caretaker_Act_I_EUROPEAN_ACADEMIC_ RESEARCH Romania Vol III Issue 3 June 2015 Impact Factor_34546_UIF_DRJI_Value_59_BISSN_2286-4822_ wwweuacademicorg_Second_Author_of_th.

11. Jamil A. An analysis of society's role in creating neurotics: a psychoanalytic reading of Pinter's The Caretaker. URL: http://www. ijern.com/journal/May-2014/08.pdf.

12. Kyllesdal M.A. The power of repetition: An analysis of repetition patterns in The Hothouse and The Caretaker by Harold Pinter. URL: https:/www.duo.uio.no/bitstream/handle/10852/25332/kyllesdal_ master.pdf?sequence $=1$.

13. Pinter H. Complete Works: Two. New York: Grove Press, 1977. 249 p.

Бернар Г. Б. Вербальна репрезентація екзистенційних проблем у п'ссі Гарольда Пінтера «Сторож»

Анотація. Статтю присвячено аналізу однієї з ранніх п'єс англомовного драматурга-абсурдиста XX-XXI століть - Гарольда Пінтера. Об'єктом дослідження є текст п’єси Г. Пінтера «Сторож», а предметом - вербальна репрезентація екзистенційних проблем у п'єсі «Сторож». Як відомо, філософія екзистенціалізму та основні ідеї А. Камю і Ж.-П. Сартра вплинули на формування жанру драми абсурду. Відповідно, мета статті - дослідити вербальну репрезентацію екзистенційних проблем у п'єсі Гарольда Пінтера «Сторож» із погляду лінгвостилістики. Зокрема, акцентовано увагу на таких екзистенційних проблемах: загроза проникнення в людську домівку; агресія та жорстокість як риса сучасного суспільства; неспроможність і небажання людини спілкуватися з іншими; замкнутість, самотність і приреченість людини в сучасному світі. У своїй п’єсі Г. Пінтер зображає нещасну маленьку людину, яка замкнулась у своїй маленькій мушлі та не хоче покидати іiі. Досліджено діалог персонажів та авторську ремарку. У статті виявлено, шо домінантними лінгвальними засобами вираження екзистенційних проблем у творі $є$ повтор на морфологічному, лексичному та синтаксичному рівнях; іронія; клімакс; апосіопеза; паралельні конструкції; заповнювачі та неповні, еліптичні речення. Часто діалог персонажів $є$ нелогічним, непослідовним із відсутніми репліками-реакціями дійових осіб на попередні висловлювання їхніх співрозмовників і з постійною зміною тем розмови через небажання головних героїв їх розвивати. Ефект відсутності спілкування між людьми та їхнє небажання соціалізуватися підсилюється ще й часто вживаною авторською ремаркою «пауза» і «тиша». Утім, висловлювання персонажів $\epsilon$ емоційно наповненим, на що вказує авторська ремарка, яка позначає той чи інший емоційний стан мовців - занепокоєння, хвилювання, страх, агресію, біль тощо.

Ключові слова: драма абсурду, філософія екзистенціалізму, екзистенційні проблеми, діалог персонажів, авторська ремарка, домінантні лінгвальні засоби. 